Seijo, G. J., M. Atahuachi, C. E. Simpson \& A. Krapovickast. 2021. Arachis inflata: A New B Genome species of Arachis (Fabaceae). Bonplandia 30(2): 169-174.

Doi: http://dx.doi.org/10.30972/bon.3024942 Recibido 23 Febrero 2021. Aceptado 7 Abril 2021.

Publicado en línea: 10 Junio 2021. Publicado impreso: 15 Agosto 2021.

ISSN 0524-0476 impreso. ISSN 1853-8460 en línea.

\title{
Arachis inflata: A New B Genome species of Arachis (Fabaceae)
}

\author{
Arachis inflata: una nueva especie de Arachis (Fabaceae) del Genoma B
}

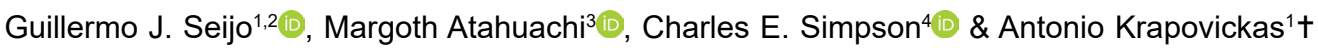

\begin{abstract}
Summary: Great efforts have been done to collect germplasm of the Arachis genus in South America, however, many regions still remain underexplored. Under the hypothesis that these regions have new and diverse populations/species of Arachis, several expeditions were carried out since 2000 in Bolivia, to increase the documentation of the genus diversity. As a first result of these explorations, a new species of section Arachis with $\mathrm{B}$ genome is formally described. Arachis inflata is closely related to $A$. magna and $A$. ipaënsis, but it can be clearly distinguished from them, and from any other species of the genus, for having a type of fruit with a completely distinct morphology. The fruit has a smooth epicarp, but shows a bullated aspect, due to the presence of air chambers in the mesocarp.
\end{abstract}

Key words: Germplasm, peanut, Planalto Chiquitano.

\begin{abstract}
Resumen: Se han realizado grandes esfuerzos para coleccionar germoplasma del género Arachis en Sudamérica, sin embargo, aún quedan muchas regiones subexploradas. Bajo la hipótesis de que estas tienen poblaciones/especies nuevas y diversas de Arachis, se realizaron nuevas expediciones en Bolivia a partir del año 2000 con el objetivo de incrementar la documentación de la diversidad de este género. Como primer resultado de estas exploraciones, en este trabajo se describe formalmente una nueva especie de la sección Arachis perteneciente al genoma B. Arachis inflata es una especie afín a A. magna y A. ipaënsis, aunque se distingue claramente de ellas, y de todas las demás especies del género, por presentar un tipo de fruto distinto. El mismo presenta epicarpo liso, con aspecto ampollado, debido a la presencia de cámaras de aire en el mesocarpo.
\end{abstract}

Palabras clave: Germoplasma, maní, Planalto Chiquitano.

\section{Introduction}

Section Arachis is the largest and more diverse taxonomic section of the homonymous genus (Krapovickas et Gregory 1994; Valls et Simpson 2005). It is composed of 31 species arranged in six different genomes: $\mathrm{A}, \mathrm{B}, \mathrm{D}, \mathrm{F}, \mathrm{G}$ and $\mathrm{K}$, with two different basic chromosome numbers $(x=9,10)$ and ploidy (2x and 4x) levels (Smartt et al., 1978; Gregory et Gregory, 1979; Fernández et Krapovickas 1994; Stalker, 1991; Seijo et al., 2004, 2007; Robledo et Seijo, 2008, 2010; Robledo et al., 2009; Silvestri et al., 2015). Germplasm of these wild species (mainly with $2 n=2 x=20$ ) is economically important, because they are the

${ }^{1}$ Instituto de Botánica del Nordeste (IBONE, UNNE-CONICET), Facultad de Ciencias Agrarias, Campus Cabral, Corrientes, Argentina. E-mail: J. G. Seijo: jgseijo@yahoo.com

${ }^{2}$ Facultad de Ciencias Exactas y Naturales y Agrimensura, Universidad Nacional del Nordeste, Campus Deodoro Roca, Corrientes, Argentina.

${ }^{3}$ Herbario Forestal Nacional Martín Cárdenas (BOLV), Centro de Biodiversidad y Genética, Universidad Mayor de San Simón, Cochabamba, Bolivia.

${ }^{4}$ Professor Emeritus, Texas A\&M AgriLife Research, Texas A\&M University, Stephenville, TX 76401, USA. 
most related to the cultivated peanut $(2 n=4 x=$ $40, \mathrm{AABB}$ ) and have several potentially useful agronomic traits for genetic improvement of the crop (Simpson, 2001; Stalker et al., 2016).

Intense germplasm collections were carried out in Argentina, Brazil and Uruguay enlarging the number of accessions maintained in the genebanks of different National or International Institutions to the present day. Even though several exploration missions for wild Arachis species were done in Bolivia, most of them concentrated in the 70's - 80's and early 90's (Valls et al., 1995), logistic difficulties for travelling by land and the enormous effort that required the expeditions at that time resulted in a sparse picture of many of the collection points. Despite the comparatively few expeditions, most of the species of section Arachis were found in Bolivia, and most of them are endemic, indicating that this country is a large center of diversity for this group of plants and deserves more attention.

Under the hypothesis that underexplored areas have new and diverse populations/ species of Arachis, we conducted a series of explorations since 2000, mainly in the Santa Cruz department of Bolivia, with the objective of increasing the documentation of the genus diversity. Those explorations were only possible thanks to the collaboration of researchers from the Instituto de Botánica del Nordeste in Corrientes (Argentina) with those from the Herbario Nacional de Bolivia in La Paz (LPB), Herbario Nacional Forestal Martín Cardenas (BOLV) in Cochabamba, and Herbarium of the Museo de Historia Natural Noel Kempff-Mercado in Santa Cruz de la Sierra (USZ), all from Bolivia; also, with the collaboration of researchers from Texas A\&M AgriLife Research, USA and Embrapa Genetic Resources and Biotechnology (CEN, Brazil). Herbarium acronyms follow Thiers (2021).

A first result of these explorations is the finding of Arachis populations that undoubtedly belong to a new B genome species of section Arachis. While searching for Arachis species in the Planalto Chiquitano, Velazco Province, Santa Cruz Department, several new populations of $A$. magna (e.g. $J$. G. Seijo, V. G. Solís Neffa, A. Schinini \& R. Almada 2996, 3022 and J. G. Seijo \& V. G.
Solís Neffa 3257, 3289; all at LPB and CTES) were found. Also, some other populations were found (like J. G. Seijo, V. G. Solís Neffa, M. Grabiele \& W. Reynoso 3637, 3640, 3649, $3653,3664,3790$ ) that resemble A. magna in the aerial organs, although they looked larger and somewhat different. A closer look to the above-ground vegetative organs revealed that the distal portion of the leaflets in the main axis of well developed plants was wider and less acute than in A. magna, and the margin of the leaflets was conspicuously whitish, due to presence of a dense layer of long hairs. Also, in most of the populations the color of the standard petal was pale orange compared to the intense orange tone commonly observed in A. magna and other Arachis species of the B genome. The great surprise came after sifting the soil. The fruit articles recovered were completely different from those expected for A. magna, with reticulated morphology. They were very large, with a smooth epicarp, and with air chambers in the mesocarp, that gave them a bullated external appearance (Fig. 1 G-H).

Further studies of the morphology, cytogenetics, molecular marker profiles and cross compatibility of these accessions with bullated fruits provided evidence that they belong to a new species of section Arachis. Here we present its formal description in the following section.

Arachis inflata Seijo, Atahuachi, C. E. Simpson \& Krapov. sp. nov. Fig. 1.

Morphologically similar to Arachis magna Krapov., W. C. Greg. \& C. E. Simpson, but differing by the generally larger plants, less acute leaflets and with whitish margin, and bullated, not reticulated, fruits, with conspicuous air chambers in the mesocarp.

Typus. Bolivia. Santa Cruz: Prov. Nuflo de Chávez, 4,2 km S de San Antonio de Lomerío, camino a San Juan de Lomerío, 16 $48^{\circ} 01^{\prime \prime} S, 61^{\circ} 50$ '24"W, 343 m, 21-I-2005, J. G. Seijo, V. G. Solís Neffa, M. Grabiele \& W. Reynoso 3637 (holotypus CTES, isotypus LPB). 


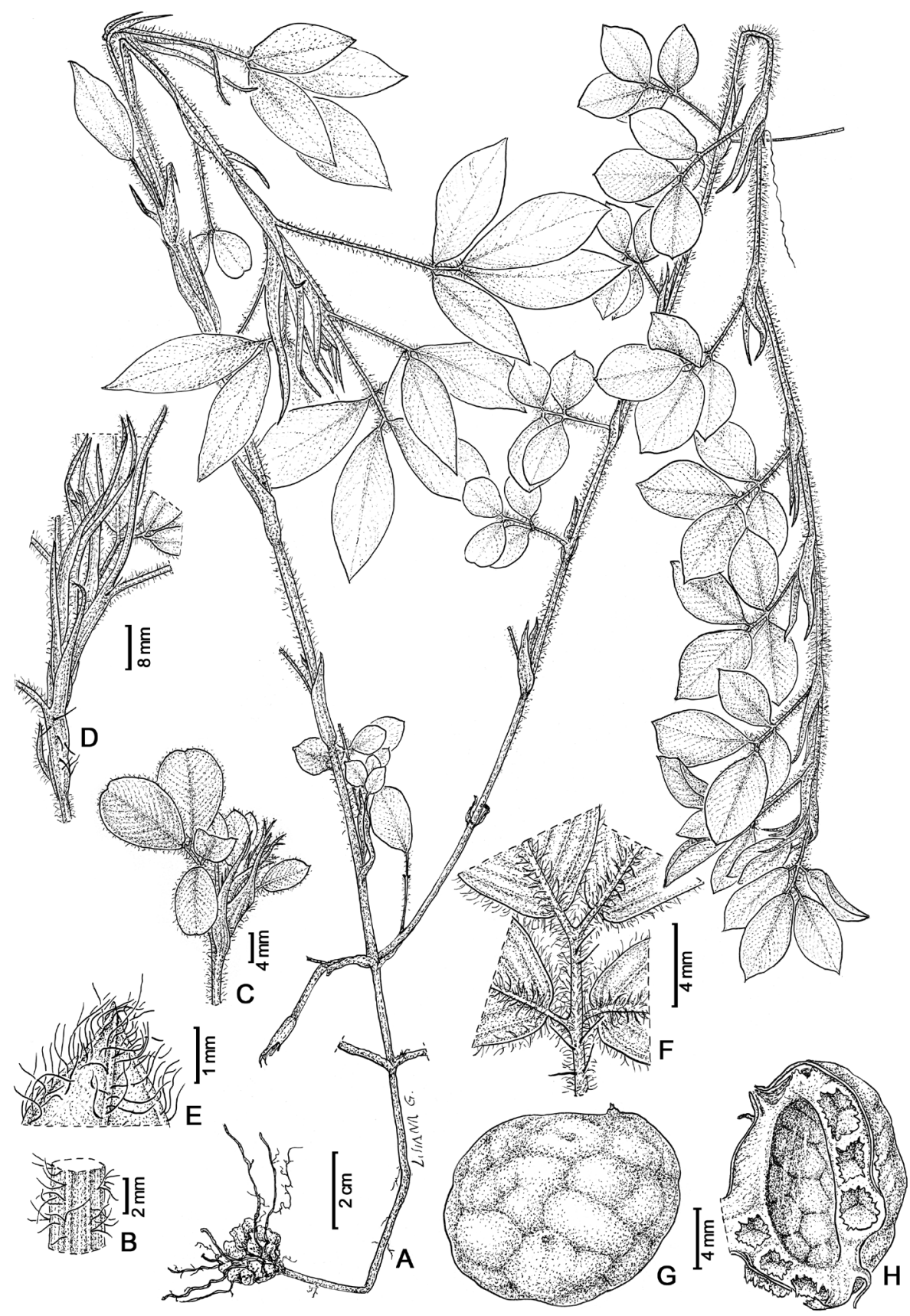

Fig. 1. Arachis inflata (Seijo et al. 3637). A: Main axis and a lateral branch of a young plant. Note remains of the fruit (that harbored the seed that gave rise to the plant) in the roots. B: Stem. C: Lateral branch apex. D: Main stem apex. E: Detail of the apex of a leaflet, lower surface. F: Petiole, rachis, midvein and lower surface of the leaflets. G: Fruit article external view, the exocarp with a bullated aspect. H: Inside view of half fruit article with the seed removed. Note the bullated aspect in the inner surface of the fruit article and the air chambers in the mesocarp (some of them were manually opened). Drawings by Liliana Gómez.

Fig. 1. Arachis inflata (Seijo et al. 3637). A: Eje principal y rama lateral de una planta joven. Se observan restos del fruto (que contenía la semilla que dio origen a la panta) en las raíces. B: Tallo. C: Ápice de la rama lateral. D: Ápice del eje principal. E: Detalle del ápice del folíolo, superficie inferior. F: Pecíolo, raquis, nervadura central y superficie inferior del folíolo. G: Vista externa de un artejo del fruto, el exocarpo con aspecto ampollado. H: Vista interna de una mitad de artejo con la semilla removida. Se observa el aspecto ampollado en la cara interna de artejo y las cámaras de aire en el mesocarpo (algunas de ellas fueron manualmente abiertas). Ilustración realizada por Liliana Gómez. 
Annual herb, weak axonomorphic root. Mainstem erect, up to $90 \mathrm{~cm}$ long, usually flowers toward the apex and with few long branches at the base. Lateral branches prostrated, up to $1.50 \mathrm{~m}$ long, stems green, rounded, or somewhat angular, quadrangular in dried specimens, villous, with wavy hairs 1.5$2 \mathrm{~mm}$ long, and few scattered bristles. Leaves tetrafoliolate. On the main-stem, stipules with the fused portion 14-20 $\mathrm{mm}$ long, the free part $28-40 \mathrm{~mm}$ long, $2.5-3 \mathrm{~mm}$ wide at the base; petiole $35-55 \mathrm{~mm}$ long; rachis $10-20$ $\mathrm{mm}$ long; leaflets oblong, apex sub-acute, the basal pair 45-52 $\mathrm{mm}$ long, $18-24 \mathrm{~mm}$ wide, and the apical one 52-63 $\mathrm{mm}$ long, 22-28 mm wide. On lateral branches, the fused part of the stipules 5-13 $\mathrm{mm}$ long, and the free part 15$22 \mathrm{~mm}$ long, 2.5-3.5 mm wide; petiole 12-22 $\mathrm{mm}$ long; rachis 5-9 $\mathrm{mm}$ long; leaflets oblong to cordate, obtuse to sub-acute, proximal pair 23-30 $\mathrm{mm}$ long, 15-20 $\mathrm{mm}$ wide, distal one 28-33 mm long, 19-22 wide. The fused part of the stipules villous, with long wavy hairs and long bristles, the free portion glabrous in most of the surface with few long hairs and bristles toward the base, margins ciliate. Petiole and rachis canaliculated, villous and with bristles; leaflets with the adaxial surface glabrous, abaxial face with sparse adpressed $1 \mathrm{~mm}$ long hairs, and wavy 1-2 mm long hairs in the midvein, margin densely ciliate with antrorse white hairs and few $1 \mathrm{~mm}$ long erect bristles. Flowers in two-four flowered spikes, hypanthium 30-60 mm long, light pink, covered with 1-2 mm long wavy hairs. Calyx light pink, villous with some sparse long bristles; upper lip 4-5 mm long; lower lip falcate, narrow, 5-6 mm long. Standard petal 9-10 $\mathrm{mm}$ long, pale orange, with orange lines on the front and yellow throat, wings yellow and keel whitish. Peg violaceous, villous in the aerial part, with wavy 1-2 mm long and scattered 1-2 mm long adpressed hairs. Fruit subterranean, biarticulated, articles ellipsoid, 15-25 mm long, 10-14 mm wide, without beak, surface smooth, bullated due to air chambers in the mesocarp. Shell thick, up to $5 \mathrm{~mm}$.

Chromosome number: $2 \mathrm{n}=20$, without large heterochromatic bands in the typical accession Seijo et al. 3637 (Seijo unpublished).
Geographic distribution and habitat: It grows in Santa Cruz Department (Bolivia), Nuflo de Chávez and Velasco provinces, Lomerío region, in the southern portion of the Planalto Chiquitano, and the northern part of the San Julian River Basin, which in turn drains into the Mamoré River. Most populations were found in the undergrowth of cerrado vegetation or in the transition between cerrado vegetation and open grassy patches, close to lagoons or water courses, in sandy soils.

Etymology: The specific epithet refers to the air chambers present in the mesocarp that gives the fruits articles an inflated aspect.

Paratype: BOLIVIA. Santa Cruz: Prov. Nuflo de Chávez, Camino de San Antonio de Lomerío a San Juan de Lomerío, 1648'02”S, 61 ${ }^{\circ} 50^{\prime} 26^{\prime}$ 'W, 328 m, 29-XI-2007, Atahuachi et al. 1390 (BOLV, CTES); 6,9 km S de San Antonio de Lomerío, 16 $6^{\circ} 48^{\prime} 30^{\prime \prime S}$, 61'51'10"W, 390 m, 31-I-2005, Seijo et al. 3640 (CTES, LPB, UCZ); id., 16²'36"S, 61'51'12"W, 29-XI-2007, Atahuachi et al. 1391 (BOLV, CTES); 18,1 km S de San Antonio, 16 $52^{\circ} 04^{\prime \prime} \mathrm{S}, 61^{\circ} 50$ '16"W, $417 \mathrm{~m}$, 21-I-2005, Seijo et al. 3649 (CTES, LPB); id., Itotoca, 16 $52^{\prime} 05^{\prime} \mathrm{S}, 61^{\circ} 50^{\prime} 13^{\prime} \mathrm{W}, 383 \mathrm{~m}$, 29-XI-2007, Atahuachi et al. 1393 (BOLV, CTES); 23,1 km S de San Antonio, 16 $6^{\circ} 4^{\prime} \mathrm{S}$, 61 ${ }^{\circ} 49^{\prime} \mathrm{W}, 21-\mathrm{I}-2005$, Seijo et al. 3653 (CTES, LPB); 39,8 km S de San Antonio, 16 ${ }^{\circ} 58^{\prime} 31^{\prime \prime S}$, 61'48'28'W, 290 m, 21-I-2005, Seijo et al. 3664 (CTES, LPB). Prov. Velasco, 31,2 km $\mathrm{S}$ de San Rafael, $17^{\circ} 01^{\prime} \mathrm{S}, 60^{\circ} 36^{\prime} \mathrm{W}, 302 \mathrm{~m}$, 8-IV-2004, Seijo \& Solís Neffa 3292 (CTES); $89,4 \mathrm{~km}$ NE de San Ignacio, $16^{\circ} 15^{\prime} 23^{\prime} \mathrm{S}$, $60^{\circ} 15^{\prime} 52 \mathrm{~W}, 280 \mathrm{~m}, 25-\mathrm{I}-2005$, Seijo et al. 3715 (CTES, LPB); $32 \mathrm{~km} \mathrm{~S} \mathrm{de} \mathrm{San} \mathrm{Rafael,}$ camino a San José, $17^{\circ} 01^{\prime} \mathrm{S}, 60^{\circ} 36^{\prime} \mathrm{W}, 288$ m, 1-II-2005, Seijo et al. 3790 (CTES, LPB); camino San Rafael-Las Petas, Hacienda San Jorge, 16³8'18'S, 5959'31'”, $212 \mathrm{~m}, 30$ XI-2007, Atahuachi et al. 1405 (BOLV, CTES).

Obs. 1: The area of A. inflata is associated with the Planalto Chiquitano, overlaps the SW area of $A$. magna and extends southward to the San Julian River. The above-ground vegetative 
appearance is similar in both species, however, they are easily distinguished by the morphology of the fruit: while A. magna has the classical reticulated ones, $A$. inflata has fruits that bear conspicuous air chambers in the mesocarp, giving the external appearance of a bullated surface. The later character of the fruit is unique in the genus Arachis. Another difference is the color of the standard petal, while in A. inflata it is pale orange, in A. magna is of a more intense tone of orange. The leaflet margin is different as well, in A. magna is poorly distinguishable while in $A$. inflata is conspicuously whitish, due to the presence of abundant long hairs.

Obs. 2: Arachis inflata does not have large heterochromatic bands in its chromosomes and has a typical karyotype of the B genome species, resembling that of $A$. magna and A. ipaënsis (Seijo et al. unpublished). Crossing data gave the following pollen stain results with $A$. inflata $\times A$. ipaënsis (K 30076) 61.3\%; A. magna (V 13761) $45.4 \%$; A. glandulifera (K 30091) 11.8\%; A. krapovickasii (Wm 1291) 8.6\%; A. batizocoi (K 9484) $2.93 \%$. These data help to solidify the separation of $A$. inflata into a new species.

Obs. 3: Moretzhon et al. (2012) studied the genetic relationships among species of section Arachis, including the accession Seijo et al. 3292 of $A$. inflata, by using intron sequences of a few nuclear genes and SSR markers. This accession of $A$. inflata grouped closely with an accession of $A$. williamsii in the cluster made on intron sequences, but with a set of $A$. magna (sister to accession V14750) in the distance tree made on SSRs markers. This data confirm that $A$. inflata belongs to the $\mathrm{B}$ genome and that there is a very low genetic distance among species in this group.

\section{Acknowledgements}

We acknowledge to the Myndel Botanica Fundation for providing funds to support the expeditions in Bolivia in 2004, 2005 (to GS) and in 2012 (to MA) and to Agencia Nacional de Promoción Científica y Tecnológica, Argentina, for contributing with funds to these expeditions and for the characterization of the materials collected (Projects PICT-2012-1875 and PICT2018-03664 to GS). We also acknowledge to all the collectors that participated in the expeditions for their help in the fieldwork. We especially thanks to Stephan Beck of LPB who made possible the initial collaborations between Argentinian and Bolivian institutions. The enormous help of the LPB Staff in obtaining the collection permits to carry out this work is greatly appreciated. The drawing of $A$. inflata is greatly acknowledged to Liliana Gómez, scientific illustrator at IBONE.

\section{Bibliography}

Fernández, A. \& Krapovickas A. (1994). Cromosomas y evolución en Arachis (Leguminosae). Bonplandia 8: 187-220. https://doi.org/10.30972/bon.81-41499

Gregory, M. P. \& Gregory W. C. (1979). Exotic germplasm of Arachis L. interspecifc hybrids. Journal of Heredity 70: 185-193.

https://doi.org/10.1093/oxfordjournals.jhered.a109231

Krapovickas, A. \& Gregory W. C. (1994). Taxonomía del género Arachis (Leguminosae). Bonplandia 8: 1-186. https://doi.org/10.30972/bon.160158

Moretzsohn, M. C., Gouvea E. G., Inglis P. W., LealBertioli S. C. M., Valls J. F. M. \& Bertioli D. J. (2013). A study of the relationships of cultivated peanut (Arachis hypogaea) and its most closely related wild species using intron sequences and microsatellite markers. Annals of Botany 111: 11326. https://doi.org/10.1093/aob/mcs237

Robledo, G. \& Seijo J. G. (2008). Characterization of Arachis D genome by FISH chromosome markers and total genome DNA hybridization. Genetic and Molecular Biology 31: 717-724.

https://doi.org/10.1590/S1415-47572008000400019

Robledo, G. \& Seijo J. G. (2010). Species relationships among the wild non-A genome of Arachis species (section Arachis) based on FISH mapping of rDNA loci and heterochromatin detection: A new proposal for genome arrangement. Theoretical and Applied Genetics 121:1033-1046. https://doi.org/10.1007/s00122-010-1369-7

Robledo, G., Lavia G. I. \& Seijo J.G. (2009). Species relations among wild Arachis species with the A genome as revealed by FISH mapping of rDNA loci and heterochromatin detection. Theoretical and Applied Genetics 118: 1295-1307. https://doi.org/10.1007/s00122-009-0981 
Seijo, J. G., Lavia G. I., Fernández A., Krapovickas A., Ducasse D. \& Moscone E. A. (2004). Physical mapping of 5S and 18S-25S rRNA genes evidences that Arachis duranensis and A. ipaënsis are the wild diploid species involved in the origin of $A$. hypogaea (Leguminosae). American Journal of Botany 91: 1294-1303. https://doi.org/10.3732/ajb.91.9.1294

Seijo, J. G., Lavia G. I., Fernández A., Krapovickas A., Ducasse D., Bertioli D. J. \& Moscone E.A. (2007). Genomic relationships between the cultivated peanut (Arachis hypogaea - Leguminosae) and its close relatives revealed by double GISH. American Journal of Botany 94: 1963-1971. https://doi.org/10.3732/ajb.94.12.1963

Silvestri, M. C., Ortiz A. M. \& Lavia G. I. (2015). rDNA loci and heterochromatin positions support a distinct genome type for ' $\mathrm{x}=9$ species' of section Arachis (Arachis, Leguminosae). Plant Systematic and Evolution 301:555-562. https://doi.org/10.1007/s00606-014-1092-y

Simpson, C. E. (2001). Use of wild Arachis species/ introgression of genes into A. hypogaea L. Peanut Science 28: 114-116. https://doi.org/10.3146/i0095-3679-28-2-12

SmartT , J., Gregory W. C. \& Gregory M. P. (1978). The genomes of Arachis hypogaea. 1. Cytogenetic studies of putative genome donors. Euphytica 27: 665-675. https://doi.org/10.3146/i0095-3679-28-2-12

STALKER, H. T. (1991). A new species in section Arachis of peanuts with a $\mathrm{D}$ genome. American Journal of Botany 78: 630-637. https://doi.org/10.1002/j.1537-2197.1991.tb12587

Stalker, H. T., Tallury S. P., Seijo J. G. \& Leal-Bertioli S. C. (2016). Biology, Speciation, and Utilization of Peanut Species. En Stalker, H. T. \& R. F. Wilson (eds.), Peanuts: Genetics, Processing, and Utilization, pp. 27-66. Academic Press and AOCS Press, United States of America. https://doi.org/10.1016/B978-1-63067-038-2.00002-2

THIERS, B. (2021). Index Herbariorum: A global directory of public herbaria and associated staff. New York Botanical Garden's Virtual Herbarium, http:// sweetgum.nybg. org/ih/. (accessed 25/01/2021).

Valls, J. F. M. \& Simpson C. E. (2005). New species of Arachis (Leguminosae) from Brazil, Paraguay and Bolivia. Bonplandia 14: 35-64. https://doi.org/10.30972/bon.141-21387

VAlls, J. F. M., Simpson C. E. \& RaO V. R. (1995). Collecting wild species of Arachis. En Guarino, L., Rao V. R. \& R. ReID (eds.), Collecting Plant Genetic Diversity. Technical Guidelines. CAB INTERNATIONAL, Wallingford. Chapter 35: 677-684. 